\title{
Dynamic compaction of sandy soils in Kuwait: A case study
}

\author{
Nabil F. Ismael* and Monera Al-Otaibi \\ Civil Engineering Department, Kuwait University, Kuwait \\ *Corresponding Author: nabil.ismael@ku.edu.kw
}

Submitted :21/05/2021

Revised :08/08/2021

Accepted : 16/08/2021

\begin{abstract}
Ground improvement was required for construction of the Jaber Al Ahmed New City located about $25 \mathrm{~km}$ west of Kuwait City, Kuwait. Loose to medium poorly graded sands and silty sands extended from ground level to a depth ranging from $5 \mathrm{~m}$ to $9 \mathrm{~m}$. Dynamic compaction was employed, as an economic method, to increase the soil bearing capacity and reduce its compressibility for foundation design and construction. The testing program included borings and sampling, Standard Penetration Tests, Cone Penetration Tests, and Pressuremeter Tests before and after dynamic compaction. The area covered in this study is about $31415 \mathrm{~m}^{2}$. The results indicated significant ground improvement and satisfaction of the specified acceptance criteria resulting in an allowable soil pressure for shallow foundation design, equal to or exceeding $300 \mathrm{kN} / \mathrm{m}^{2}$.
\end{abstract}

Keywords: Sands; Soil tests; Dynamic compaction; Standard penetration tests; Cone penetration tests, Pressuremeter Tests.

\section{INTRODUCTION}

With major economic development and population increase, Kuwait has started the construction of new cities in the desert. One of these cities is Jaber Al Ahmed New City located $25 \mathrm{~km}$ west of Kuwait City. Preliminary soil investigation revealed loose to medium dense sands and silty sands extending up to $9 \mathrm{~m}$ below ground level underlain by dense to very dense sands. This is typical of the ground conditions in Kuwait (Ismael et al. 1986). The ground water level was encountered at a depth of $3 \mathrm{~m}$ below ground level. With no gravel in the soil samples and with the fines content $(<0.075 \mathrm{~mm})$ ranging from $10 \%$ to $15 \%$ on average, dynamic compaction was recommended to the Public Authority for Housing Welfare (PAHW) as an effective and economic method for ground improvement. Dynamic compaction has been used for ground improvement of the Sabkha deposits, which exist along the Arabian Gulf region (Moon et al. 2019). This is a salt flat or a salt bearing soil consisting of fine silt or clayey silt with a large percentage of carbonates and sulphates. Dynamic compaction was used for densification of sand fill formed by hydraulic filling (Bo et al. 2009, Khelalfa 2017) and as a cost-effective alternative to pile foundations for sites consisting of deep deposits of loose granular soils (Ali and Ali, 2008) and for compacting sand filling embankment (Chen 2012). Studies to estimate the dynamic compaction effect in sand and the depth of improvement were carried out (Lee and Gu 2004, Kundu and Viswanadhan 2016), and the effect on the liquefaction of reclaimed ground was investigated by Shen (2018). 
An area of $31416 \mathrm{~m}^{2}$ consisting of six subzones was selected in the present study. Dynamic compaction was achieved using a pounder $1.8 \mathrm{~m} \times 1.8 \mathrm{~m}$ weighing 15 ton and dropping from a height of 14 to $16 \mathrm{~m}$ with 4 to 6 blows at each point, and in three phases and followed by an ironing phase. Soil conditions were determined before ground improvement by boreholes and Standard Penetration Tests SPT, Cone Penetration tests CPT, and Pressuremeter Tests (PMT). The same tests were repeated after dynamic compaction as the quality control tests to determine the improvement made and whether it met the acceptance criteria set before the beginning of the work. The criteria were based on achieving the minimum allowable soil pressure of $300 \mathrm{kN} / \mathrm{m} 2$ required for foundation design of the housing structures and other infrastructure services and facilities in the new city. The allowable pressure is determined from Bowles (1977) Equation based on the SPT test values and an allowable settlement of $25 \mathrm{~mm}$

This paper presents a well-documented case study of dynamic compaction in the arid desert environment of the State of Kuwait. No case studies are available for the local soils. The equipment and procedure employed, the improvements in the soil parameters, and the penetration test values are presented for the benefit of the practicing geotechnical engineers and researchers.

\section{SOIL CONDITIONS}

Figure 1 shows a plan of the area under investigation, which consists of six subzones, with each having an area of 4000 to $6000 \mathrm{~m}^{2}$. One borehole, cone tests at three locations, and one hole for the Pressuremeter Tests were drilled in each subzone. The boreholes were advanced by augering. Standard Penetration Tests were carried out at $0.5 \mathrm{~m}$ intervals till $4.0 \mathrm{~m}$ from existing ground surface, and then at $1.0 \mathrm{~m}$ intervals up to the end of the boreholes. The depth of the boreholes was $11.5 \mathrm{~m}$. Laboratory tests were performed on the selected samples recovered during the field investigation for classification and for the determination of the basis properties. Figure 2 shows the soil description and the Standard Penetration Test N values for the six boreholes. The soil profile consists of calcareous granular material, which was found to be generally alternate layers of poorly graded sand with silt (SP-SM) and silty sand (SM). Based on the SPT-N values, the relative density of the granular material can be classified as loose soils in the top $1.0 \mathrm{~m}$ followed by medium dense to dense up to $9.0 \mathrm{~m}$ and then followed by dense soil till the end of the boreholes. All samples were nonplastic with no gravel and fines content of about $10 \%$. The moisture content was limited to $5 \%$ in the upper $2 \mathrm{~m}$ increasing gradually to $15 \%$ with depth. Ground water was encountered in the boreholes at a depth of $3.0 \mathrm{~m}$ below the ground level.

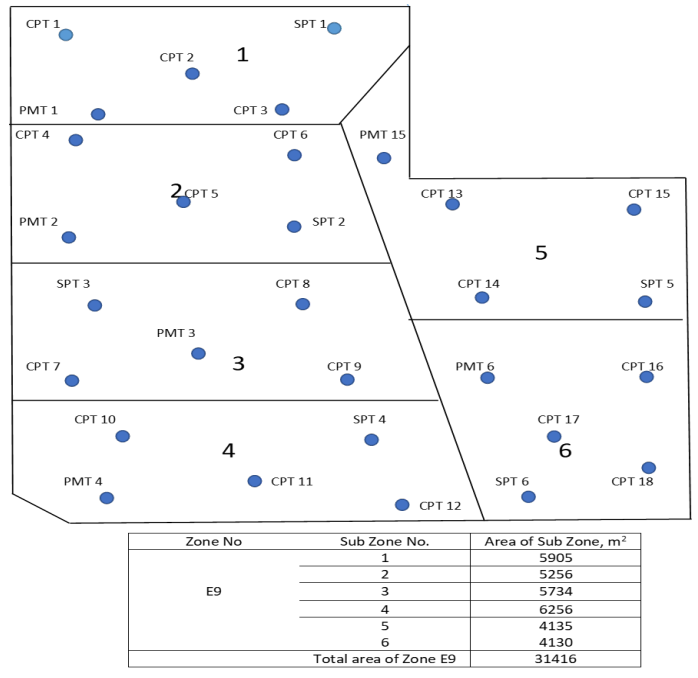

Figure 1. Plan of the area and field test locations. 


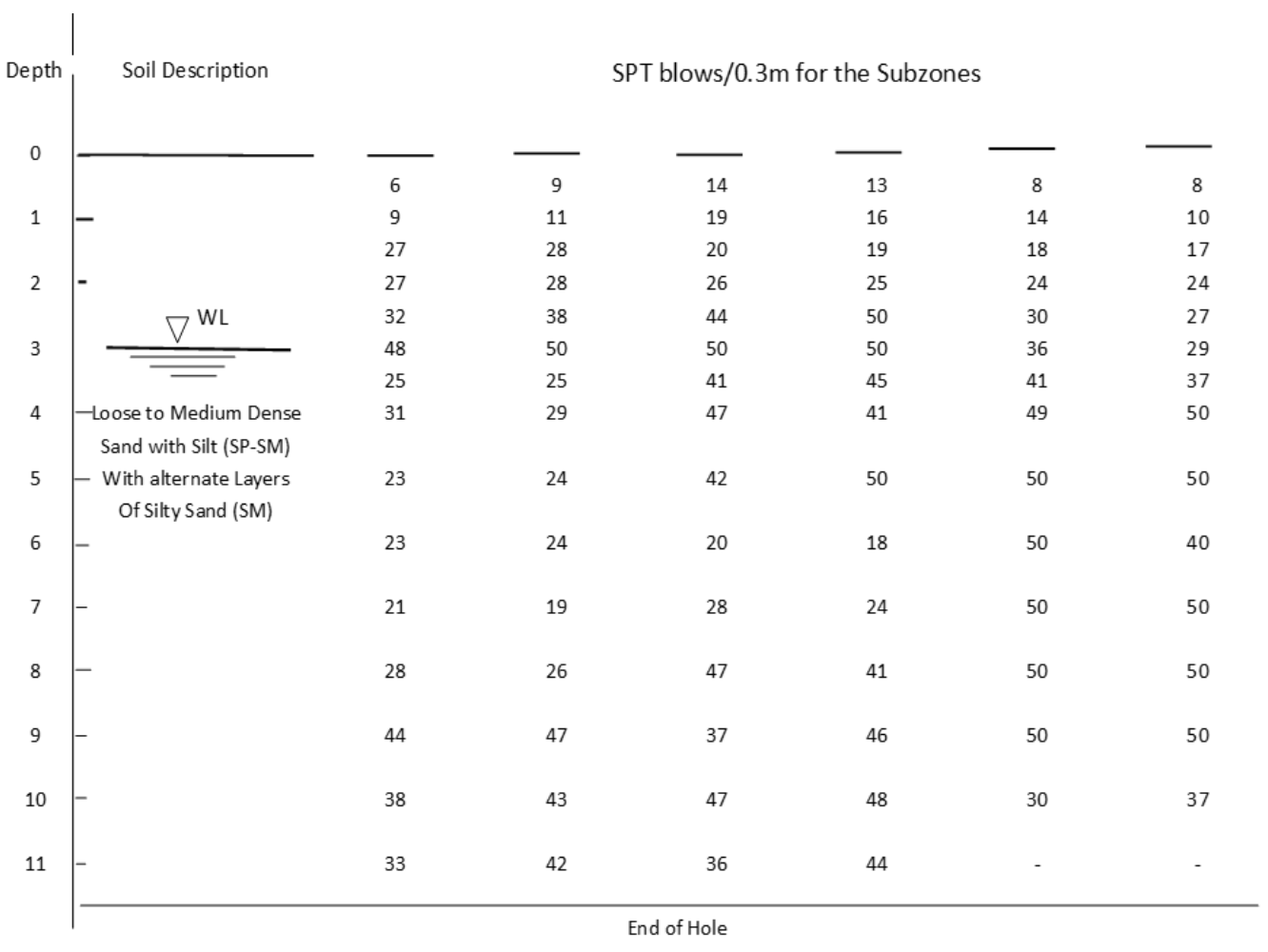

Figure 2. Soil description and Standard Penetration Test $\mathrm{N}$ values.

\section{Cone Penetration Tests (CPTs)}

Eighteen CPTs were conducted a per ASTM D-5778 at the locations shown in Figure 1. For each zone, three cone tests were performed. A cordless cone manufactured by Geotech $\mathrm{AB}$, Sweden, was pushed into the soil at a constant penetration rate, using a 20 ton $(200 \mathrm{kN})$ hydraulic powered capacity, lorry mounted, pushing unit. Based on the CPT results the cone resistance $\mathrm{q}_{\mathrm{c}}$, the sleeve friction $\mathrm{f}_{\mathrm{s}}$ and the friction ratio $\mathrm{F}_{\mathrm{r}}$ were determined with depth until refusal was encountered below $3.5 \mathrm{~m}$ depth. The average value of $\mathrm{q}_{\mathrm{c}}$ ranged from $16.77 \mathrm{MPa}$ to $23.95 \mathrm{MPa}$. The sleeve friction $\mathrm{f}_{\mathrm{s}}$ and the friction ratio $\mathrm{F}_{\mathrm{r}}$ ranged from $0.22 \mathrm{MPa}$ to $0.31 \mathrm{MPa}$ and from $1.09 \%$ to $1.99 \%$, respectively, for the six subzones.

\section{Pressuremeter Tests (PMTs)}

Pressuremeter tests were conducted at six locations, one location in each zone as shown in Figure 1. The Pressuremeter test device consists of a pressure cell and two guard cells. A probe with OD $44 \mathrm{~mm}$ installed into a slotted casing with OD $63 \mathrm{~mm}$ was used. Percussion driving was used to penetrate the probe into the soil. Tests were performed at one-meter intervals down to $10 \mathrm{~m}$ or until refusal occurred. The criteria for refusal are reached if $0.5 \mathrm{~m}$ penetration of the device required more than $120 \mathrm{sec}$. The test involves expanding the pressure cell inside the borehole at a certain depth and measuring the expansion of its volume after each increment of pressure. The test data were interpreted on the basis of the theory of expansion of the cylindrical cell under cell pressure. Refusal occurred below a depth of $3 \mathrm{~m}$. For this case, the limit pressure is considered as exceeding 3.0 MPa. The average measured values ranged from 1.2MPa to 2.45 $\mathrm{MPa}$ for the limit pressure PL and 11.6 MPa to 41.5 MPa for the soil modulus Em. 


\section{ACCEPTANCE CRITERIA FOR SOIL IMPROVEMENT}

To meet the foundation design requirements at the Jaber Al-Ahmed New City site with regard to the allowable pressure and compressibility of the ground soils, the following acceptance criteria were specified for the soils to a depth of $7 \mathrm{~m}$.

\section{SPT Tests}

For the top $4 \mathrm{~m}$ from the original ground surface, the average $\mathrm{N}$ values shall not be less than 25 with the minimum value not less than 20 . The average $\mathrm{N}$ value from 4 to $7 \mathrm{~m}$ depth shall not be less than 20 , with the minimum value not less than 15 .

\section{CPT Tests}

For the top $4.0 \mathrm{~m}$ from the original ground surface, the average cone resistance $\mathrm{q}_{\mathrm{c}}$ shall not be less than $15 \mathrm{MPa}$ with the minimum value not less than $12 \mathrm{MPa}$. The corresponding values from 4 to $7 \mathrm{~m}$ are $12 \mathrm{MPa}$ and $10 \mathrm{MPa}$, respectively.

\section{PMT Tests}

For the top $4 \mathrm{~m}$ from the original ground surface, the average limit pressure $\mathrm{PL}_{\mathrm{L}}$ shall not be less than $1.5 \mathrm{MPa}$ with the minimum value not less than 1.2 $\mathrm{MPa}$. The corresponding values from 4 to $7 \mathrm{~m}$ are $1.2 \mathrm{MPa}$. and $1.0 \mathrm{MPa}$, respectively.

The above limits of the acceptance criteria, which are summarized in Table 1, should be attained at any point within the treated area at four weeks after the completion of the soil improvement.

Table 1. Acceptance criteria for dynamic compaction.

\begin{tabular}{|c|c|c|c|c|c|c|}
\hline Test & \multicolumn{2}{|c|}{ CPT } & \multicolumn{2}{c|}{ SPT } & \multicolumn{2}{c|}{ PMT } \\
\hline $\begin{array}{c}\text { Depth } \\
(\mathrm{m})\end{array}$ & $0-4 \mathrm{~m}$ & $4 \mathrm{~m}-7 \mathrm{~m}$ & $0-4 \mathrm{~m}$ & $4 \mathrm{~m}-7 \mathrm{~m}$ & $0-4 \mathrm{~m}$ & $4 \mathrm{~m}-7 \mathrm{~m}$ \\
\hline DC & \multicolumn{2}{|c|}{ qc(MPa) } & \multicolumn{2}{c|}{ N Value } & \multicolumn{2}{c|}{ PL(MPa) } \\
\hline Min. $\geq$ & 12 & 10 & 20 & 15 & 1.2 & 1 \\
\hline Ave. $\geq$ & 15 & 12 & 25 & 20 & 1.5 & 1.2 \\
\hline
\end{tabular}

\section{DYNAMIC COMPACTION DETAILS}

The basic concept of dynamic compaction is to apply the energy required for the improvement of a given depth of the weak soil. The energy is applied through the repeated drops of a designed weight (tamper) from a designed height above the ground. The depth of formed crater under the applied energy is a tentative measure of the amount of improvement. The governing equation of the dynamic compaction may be expressed as

$\mathrm{D}=\mathrm{n}(\mathrm{WH})^{0.5}$

where $\mathrm{D}=$ depth of improvement $(\mathrm{m}), \mathrm{n}=$ coefficient depending on the soil type and ranges between 0.3 and $0.8, \mathrm{~W}=$ weight of drop tamper (ton), and $\mathrm{H}=$ drop height. 
The improvement by the dynamic compaction technique was applied on a square grid pattern between compaction points with spacing nearly twice the equivalent diameter of the drop weight. The tamper used is $1.8 \mathrm{~m}$ $\mathrm{x} 1.8 \mathrm{~m}$ weighing 15 ton and dropping $14 \mathrm{~m}$ to $16 \mathrm{~m}$ at a grid spacing of $4.25 \mathrm{~m}$. Applying Equation (1) with $\mathrm{n}=0.45$, $\mathrm{D}$ is nearly $7 \mathrm{~m}$. Figure 3 shows the layout of the impact points and the compaction phases.

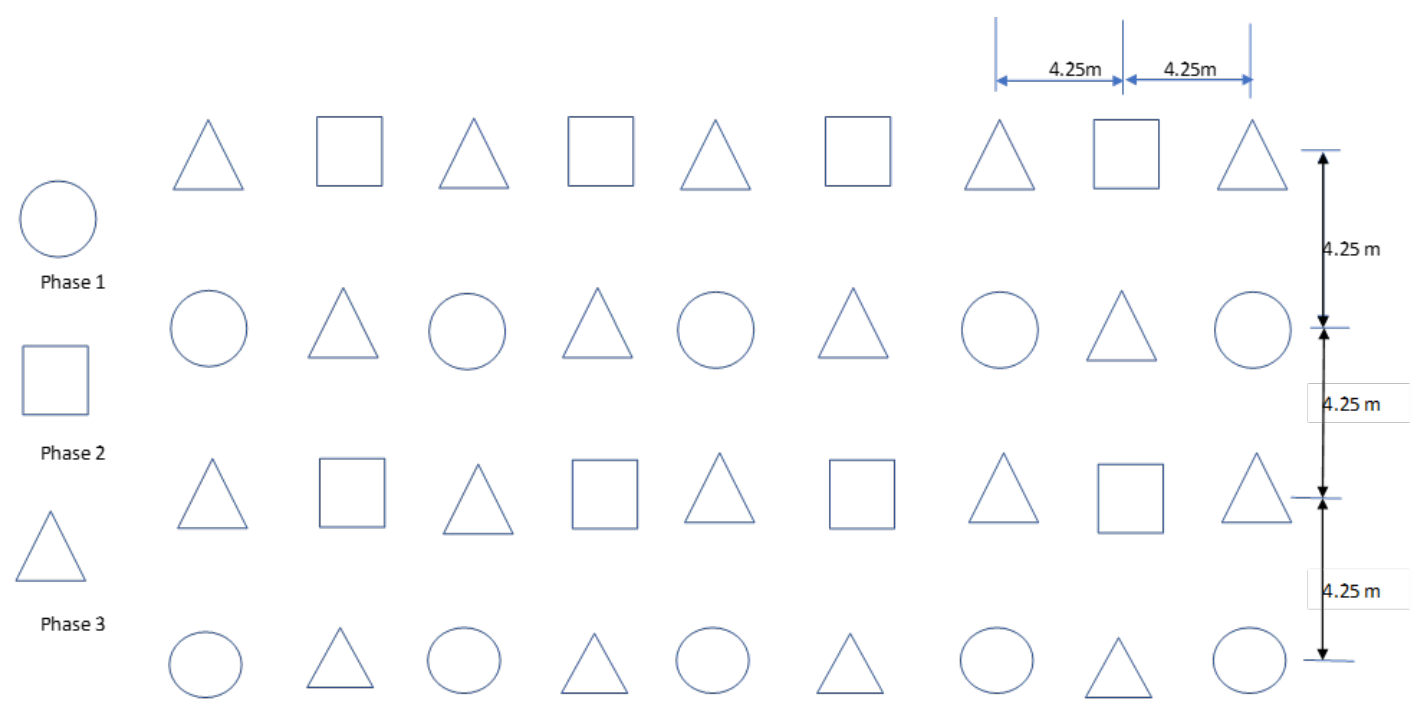

Figure 3. Layout plan of the impact points and phases of dynamic compaction.

Prior to the commencement of the production phase of the ground improvement work, dynamic compaction was carried out in a test section having an area of $2500 \mathrm{~m}^{2}$. This is to calibrate several parameters that will be used in the production phase. The parameters included the drop weight, the height of drop, the base configuration of the drop weight, the spacing and pattern of imprints, the number of drops per imprint, the number of passes, and the time delay between the passes if required. Table 2 shows a summary of the compaction phases. As shown, each phase consists of one pass with 4 to 6 blows at each point. After each dynamic compaction phase, the craters were filled with imported granular material having finer content not exceeding $30 \%$ and the plasticity index not exceeding $8 \%$. The ground surface was leveled and prepared for the next compaction phase. In all cases, an additional pass to compact the surface soils (ironing pass) was performed after the successful application of the dynamic compaction with the details shown in Table 2. During the dynamic compaction operations, the application of an energy stopped when any of the following occurred:

a) The depth of the crater is greater than the thickness of the drop weight plus $0.3 \mathrm{~m}$. In this case, the crater was backfilled, and compaction resumed.

b) A heave of the ground surface occurred prior to reaching the required numbers of drops. In this case, time was given prior to resuming the compaction to allow for pore water pressure dissipation.

c) Ground water appeared within the crater. In this case, the crater is backfilled, and compaction resumed. 
Table 2. Summary of the dynamic compaction phases.

\begin{tabular}{|c|c|c|c|}
\hline Phase 1 & & & \\
\hline \multicolumn{2}{|c|}{ Pass 1} & \multicolumn{2}{|c|}{ Ironing } \\
\hline from & $13 / 06 / 2011$ & from & $23 / 06 / 2011$ \\
\hline to & $22 / 06 / 2011$ & to & $30 / 06 / 2011$ \\
\hline \multicolumn{2}{|c|}{ Pounder } & \multicolumn{2}{|c|}{ Pounder } \\
\hline Surface & $1.8 \mathrm{~m} \times 1.8 \mathrm{~m}$ & Surface & $1.8 \mathrm{~m} \times 1.8 \mathrm{~m}$ \\
\hline Weight & $15 \mathrm{t}$ & Weight & $15 \mathrm{t}$ \\
\hline Blows & 4 to 6 & Blows & 2 to 4 \\
\hline Height & 14 to $16 \mathrm{~m}$ & Height & 8 to $10 \mathrm{~m}$ \\
\hline \multicolumn{4}{|l|}{ Phase 2} \\
\hline \multicolumn{2}{|c|}{ Pass 1} & \multicolumn{2}{|c|}{ Ironing } \\
\hline from & $13 / 06 / 2011$ & from & $23 / 06 / 2011$ \\
\hline to & $22 / 06 / 2011$ & to & $30 / 06 / 2011$ \\
\hline \multicolumn{2}{|c|}{ Pounder } & \multicolumn{2}{|c|}{ Pounder } \\
\hline Surface & $1.8 \mathrm{~m} \times 1.8 \mathrm{~m}$ & Surface & $1.8 \mathrm{~m} \times 1.8 \mathrm{~m}$ \\
\hline Weight & $15 \mathrm{t}$ & Weight & $15 \mathrm{t}$ \\
\hline Blows & 4 to 6 & Blows & 2 to 4 \\
\hline Height & 14 to $16 \mathrm{~m}$ & Height & 8 to $10 \mathrm{~m}$ \\
\hline \multicolumn{4}{|l|}{ Phase 3} \\
\hline \multicolumn{2}{|c|}{ Pass 1} & \multicolumn{2}{|c|}{ Ironing } \\
\hline from & $13 / 06 / 2011$ & from & $23 / 06 / 2011$ \\
\hline to & $22 / 06 / 2011$ & to & $30 / 06 / 2011$ \\
\hline \multicolumn{2}{|c|}{ Pounder } & \multicolumn{2}{|c|}{ Pounder } \\
\hline Surface & $1.8 \mathrm{~m} \times 1.8 \mathrm{~m}$ & Surface & $1.8 \mathrm{~m} \times 1.8 \mathrm{~m}$ \\
\hline Weight & $15 \mathrm{t}$ & Weight & $15 \mathrm{t}$ \\
\hline Blows & 4 to 6 & Blows & 2 to 4 \\
\hline Height & 14 to $16 \mathrm{~m}$ & Height & 8 to $10 \mathrm{~m}$ \\
\hline
\end{tabular}




\section{TEST RESULTS AFTER DYNAMIC COMPACTION}

The initial tests conducted were repeated after ground improvement by dynamic compaction for quality control to ensure satisfaction of the acceptance criteria. For each subzone, one boring was drilled, cone tests at three points, and one hole for Pressuremeter tests next to the initial locations. Figure 4 shows the SPT-N values before and after ground improvement up to a depth of $8 \mathrm{~m}$ for subzones 1 to 4 . As shown, the $\mathrm{N}$ values increased and satisfied the acceptance criteria. Figure 5 shows the cone resistance with depth $\mathrm{q}_{\mathrm{c}}$, before and after dynamic compaction for subzones 1 to 5. A remarkable increase in the value of $\mathrm{q}_{\mathrm{c}}$ is noted along the entire depth with the values meeting the acceptance criteria. The values increased to at least twice the original values. At a depth of $3.5 \mathrm{~m}$, refusal was encountered as the maximum reaction capacity was reached. Figure 6 shows the Pressuremeter test results for subzones 1 to 3 . For each subzone, the variations of the limit pressure and the Pressuremeter modules with depth are shown before and after ground improvement. Refusal was encountered at a depth of $3 \mathrm{~m}$ after dynamic compaction. From Figure 6, it is noted that both the limit pressure $P_{L}$ and the soil modulus E have increased by two times or more compared to their initial values after dynamic compaction. These values satisfied the acceptance criteria.

\section{DISCUSSION}

The above results indicated the effectiveness of dynamic compaction for ground improvement of loose and medium dense sands and silty sands to a depth of $7 \mathrm{~m}$. The method is ideal for new areas where no buildings or nearby structures exist. The results show a significant increase in strength and reduced compressibility after dynamic compaction. This is evident by the increase in the $\mathrm{N}, \mathrm{qc}$, and $\mathrm{E}$ values with depth. Noting that the dynamic compaction is economically effective, significant saving is achieved in foundation design and construction costs due to the higher values of the allowable soil pressure and the smaller settlement expected under foundation loads. It should be emphasized that dynamic compaction is suited for sands and silty sands with fine content $(<0.075 \mathrm{~mm})$ less than $30 \%$ and the friction ratio $\mathrm{Fr}<2 \%$ and no ground heave due to development of excess pore water pressure. The depth of ground improvement can be increased if required to $10 \mathrm{~m}$ by increasing the compaction energy. This can be done by increasing the drop weight, or the drop height, or both.

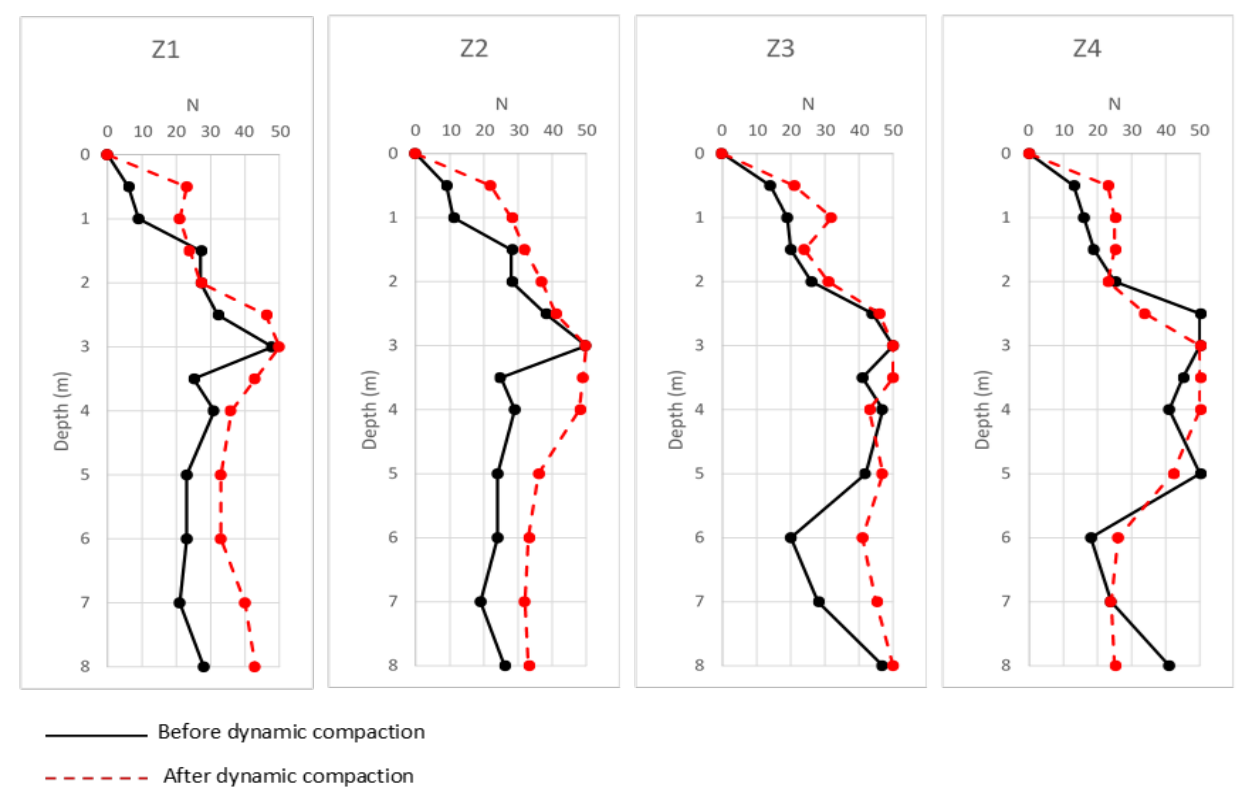

Figure 4. Standard Penetration Test results before and after dynamic compaction for zones 1 to 4 . 

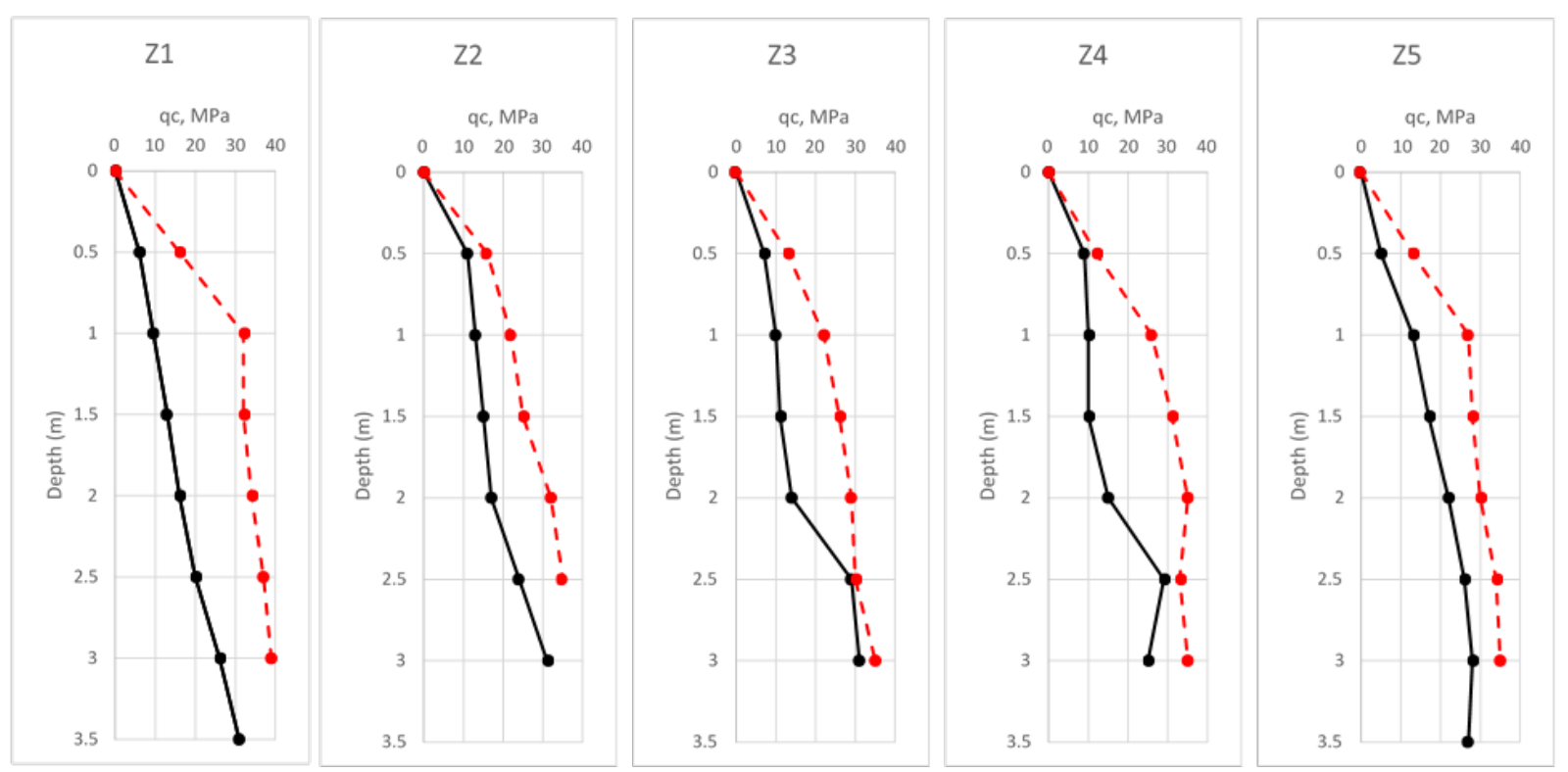

Before dynamic compaction

- - - - - After dynamic compaction

Figure 5. Cone Penetration Test results before and after dynamic compaction for zones 1 to 5.
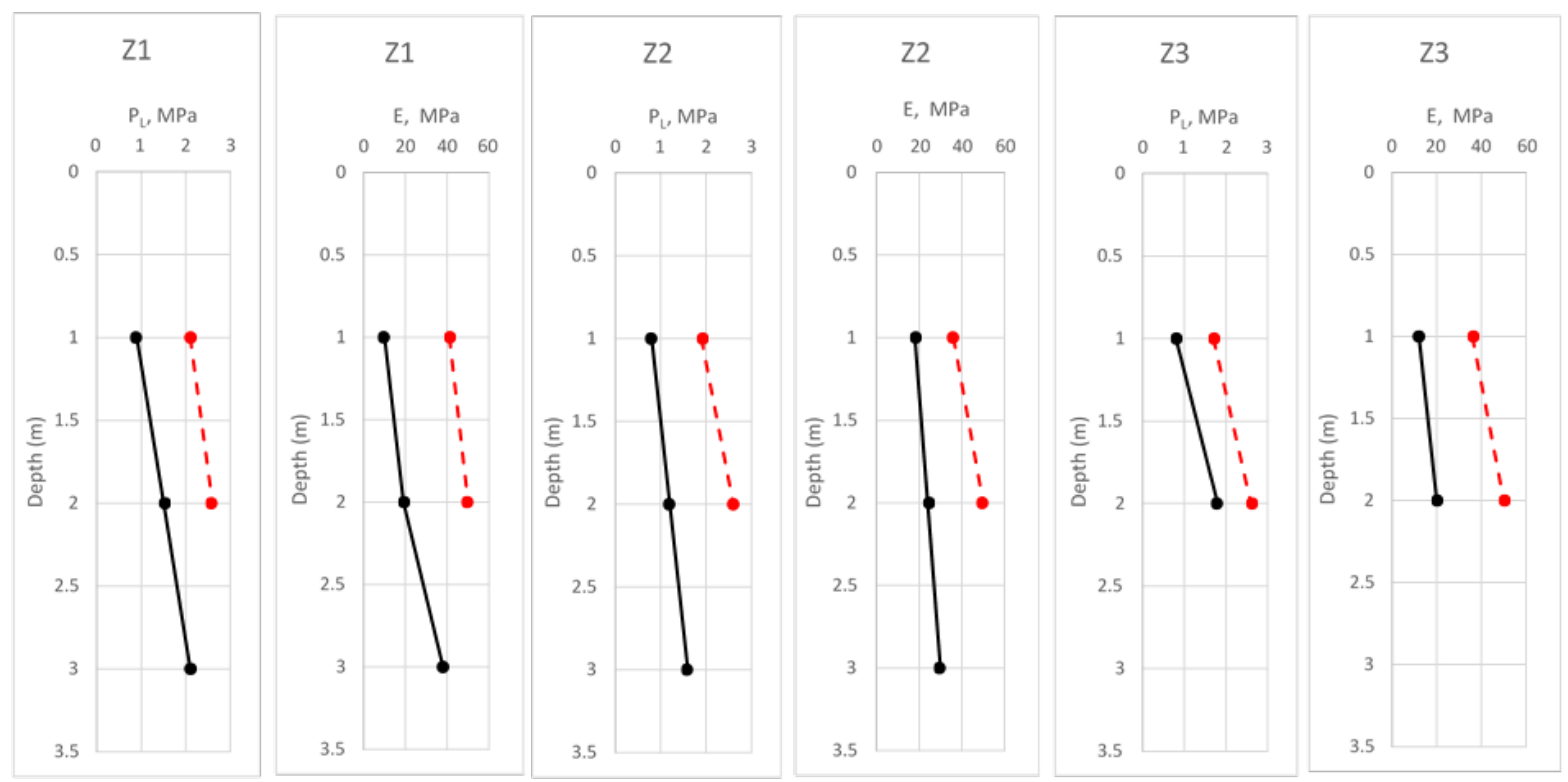

Before dynamic compaction

Figure 6. Limit pressure and soil modulus before and after dynamic compaction for zones 1 to 3 . 


\section{CONCLUSIONS}

Dynamic compaction was employed for ground improvement to a depth of $7 \mathrm{~m}$ in an area of the new Jaber AlAhmed City in Kuwait. Laboratory tests and field tests including borings, Penetration Tests, and Pressuremeter Tests were carried out before and after dynamic compaction. Based on test results, the following conclusions can be drawn:

1. The soil profile in the test area consists of loose to medium dense poorly graded sands with silt and silty sands to a depth of $9 \mathrm{~m}$ followed by dense sands, with water level $3 \mathrm{~m}$ below ground surface.

2. Dynamic compaction employing 15 ton drop weight from a height of 14 to $16 \mathrm{~m}$ in three phases followed by an ironing phase resulted in a significant increase in the strength and reduced compressibility.

3. Standard Penetration Tests and Cone Penetration tests before and after dynamic compaction indicated that the $\mathrm{N}$ and $\mathrm{q}_{\mathrm{c}}$ values increased substantially as the ground changed from loose, and medium dense to dense ground conditions.

4. As a result of dynamic compaction, the minimum allowable pressure of $300 \mathrm{kN} / \mathrm{m}^{2}$ required for foundation design by the Public Authority for Housing Welfare was exceeded.

5. The soil compressibility decreased significantly after dynamic compaction. The soil modulus E determined from the Pressuremeter Tests has more than doubled after dynamic compaction.

6. The method of dynamic compaction is recommended for other areas in the Gulf States where loose desert sands and silty sands extend to a depth of up to $10 \mathrm{~m}$ with the fines content less than $30 \%$, and the water level is relatively deep, and where new cities or large compounds will be constructed in the desert.

\section{REFERENCES}

Ali, L. and Ali, S. (2008). "Enhancement of Bearing Capacity by Dynamic Compaction: A case History". Proceedings of the $6^{\text {th }}$ International Conference on Case Histories in Geotechnical Engineering, Arlington, VA, paper No $7.25 \mathrm{a}$

Bo, M.W., Na, Y.M., Arulrajah, A., and Chang, M.F. (2009). Densification of granular soils by dynamic compaction. Proceedings of the Institute of Civil Engineers, Ground Improvement 162, Issue G13, pp. $121-132$

Bowles. (1977). Foundation Analysis and Design, $2^{\text {nd }}$ ed., McGraw-Hill, New York

Chen, C. (2012) Effect of dynamic compaction on red sand soil filling embankment. Applied Mechanics and Materials, pp. 788-791.

Ismael, N.F., Jeragh, A.M., Mollah, M.A., and Al Khaldi, O. (1986). A study of the properties of surface soils in Kuwait. Journal of the Southeast Asian Geotechnical Society, Bangkok, Thailand, No. 1, Volume 17, pp. 67-87, June.

Khelalfa, H. (2017) Dynamic compaction with high energy of sandy coastal embankment. International Symposium on Construction Management and Civil Engineering, November, Algeria

Kundu, S. and Viswanadham, B.(2016). Studies to evaluate the impact of tamper on the depth of improvement in dynamic compaction. Proceedings of the $15^{\text {th }}$ Asian Regional Conference on Soil Mechanics and Geotechnical Engineering, pp 2033-2037.

Lee, F.H., and Gu, Q. (2004). Method for estimating dynamic compaction effect on sand. Journal of Geotechnical and Geo environmental Engineering, ASCE, 130 (2): 139-152 
Moon, J., Jung, H., Lee, S.,and Kang, S.(2019). Ground improvement using dynamic compaction in Sabkha Deposit. Applied Sciences 9, 2506.

Shen, M., Martin, J.,Ku,C., and Lu, Y. (2018). A case study of the effect of dynamic compaction on the liquefaction of reclaimed ground. Engineering Geology 240, 48-61 